\title{
PEMERIKSAAN IVA TEST PADA WANITA USIA SUBUR DI DESA PANGKALAN LADA
}

\author{
${ }^{1}$ Angela Ditauli Lubis \\ ${ }^{1}$ STIKes Borneo Cendekia Medika Pangkalan Bun \\ ${ }^{1}$ Email : angela.lubis03@gmail.com
}

\begin{abstract}
ABSTRAK
Jumlah penderita kanker serviks di Indonesia semakin tinggi. Promosi kesehatan dan deteksi dini menjadi prioritas untuk mencegah dan menangani penyakit. Organisasi Kesehatan Dunia (WHO) mencatat, tiap tahun sekitar 15.000 kasus kanker serviks (leher rahim) ditemukan di Indonesia. Indonesia menjadi negara dengan jumlah kasus kanker serviks tertinggi di dunia. Kanker serviks ditandai dengan tumbuhnya sel-sel tidak normal pada leher rahim. Diperkirakan 90 persen kanker leher rahim disebabkan human papillomavirus (HPV). Insiden kanker serviks sebenarnya dapat ditekan dengan melakukan upaya pencegahan primer seperti meningkatkan atau intensifikasi kegiatan penyuluhan kepada masyarakat untuk menjalankan pola hidup sehat, menghindari faktor risiko terkena kanker, melakukan immunisasi dengan vaksin HPV dan diikuti dengan deteksi dini kanker serviks tersebut melalui pemeriksaan pap smear atau IVA (inspeksi visual dengan menggunakan asam acetat). Saat ini cakupan "screening" deteksi dini kanker serviks di Indonesia melalui pap smear dan IVA masih sangat rendah (sekitar 5\%), padahal cakupan "screening" yang efektif dalam menurunkan angka kesakitan dan angka kematian karena kanker serviks adalah $85 \%$. Sasaran dalam kegiatan penyuluhan ini adalah seluruh perempuan yang telah menikah di Desa Pangkalan Lada. Metode yang dilakukan dalam kegiatan ini adalah penyuluhan dan pemeriksaan IVA gratis. Kegiatan pemeriksaan IVA Test pada wanita usia subur di desa Pangkalan Lada berjalan dengan baik. Antusias dari para peserta cukup baik. Jumlah peserta yang mengikuti pemeriksaan IVA sebanyak 45 orang. Berdasarkan hasil pemeriksaan IVA yang dilakukan pada wanita usia subur di desa Pangkalan Lada, dari 40 peserta yang dilakukan pemeriksaan 10 diantaranya mengalami erosi dan 5 orang diberikan tutul albothyl dan selanjutnya disarankan untuk melakukan pap smear. Pemeriksaan IVA Test tujuan kegiatan ini adalah untuk mendeteksi dini kanker leher rahim pada wanita usia subur. Agar kegiatan pemeriksaan seperti ini dapat dilakukan secara rutin sehingga derajat kesehatan warga khususnya pada wanita-wanita di desa ini dapat meningkat dan terpantau.
\end{abstract}

\section{Kata kunci : IVA Test, Wanita Usia Subur \\ IVA TEST EXAMINATION IN SUBUR AGED WOMEN IN PANGKALAN PEPPER VILLAGE}

\begin{abstract}
The number of cervical cancer sufferers in Indonesia is getting higher. Health promotion and early detection are priorities to prevent and manage disease. The World Health Organization (WHO) notes, every year around 15,000 cases of cervical cancer (cervix) are found in Indonesia. Indonesia is the country with the highest number of cervical cancer cases in the world. Cervical cancer is characterized by the
\end{abstract}


growth of abnormal cells in the cervix. It is estimated that 90 percent of cervical cancers are caused by human papillomavirus (HPV). The incidence of cervical cancer can actually be suppressed by making primary prevention efforts such as increasing or intensifying counseling activities to the community to run a healthy lifestyle, avoiding risk factors for developing cancer, immunizing with the HPV vaccine and followed by early detection of cervical cancer through pap smear examination or IVA (visual inspection using acetic acid). At present the coverage of "screening" for early detection of cervical cancer in Indonesia through pap smears and IVA is still very low (around 5\%), even though the coverage of "screening" that is effective in reducing morbidity and mortality due to cervical cancer is $85 \%$. The targets in this outreach activity are all married women in Pangkalan Lada Village. The method used in this activity is counseling and free IVA examination. The IVA Test on women of childbearing age in the village of Pangkalan Lada is going well. The enthusiasm of the participants was quite good. 45 participants took part in the IVA examination. Based on the results of IVA examinations carried out on women of childbearing age in the village of Pangkalan Lada, of the 40 participants who carried out the examination 10 of them experienced erosion and 5 people were given spotted albothyl and subsequently advised to do a pap smear. IVA Examination The purpose of this activity is to detect cervical cancer early in women of childbearing age. So that inspection activities like this can be done routinely so that the health status of residents, especially women in this village can be improved and monitored.

\section{Pendahuluan}

Jumlah penderita kanker serviks di Indonesia semakin tinggi. Promosi kesehatan dan deteksi dini menjadi prioritas untuk mencegah dan menangani penyakit. Organisasi Kesehatan Dunia (WHO) mencatat, tiap tahun sekitar 15.000 kasus kanker serviks (leher rahim) ditemukan di Indonesia. Indonesia menjadi negara dengan jumlah kasus kanker serviks tertinggi di dunia. Kanker serviks ditandai dengan tumbuhnya sel-sel tidak normal pada leher rahim. Diperkirakan 90 persen kanker leher rahim disebabkan human papillomavirus (HPV).

Di Indonesia, tiap tahun diperkirakan terdapat 100 penderita baru per 100.000 penduduk. Ini berarti dari jumlah 237 juta penduduk, ada sekitar 237.000 penderita kanker baru setiap tahunnya. Sejalan dengan itu, data empiris juga menunjukkan bahwa kematian akibat kanker dari tahun ke tahun terus meningkat. Berdasarkan hasil Riskesdas tahun 2007, sekitar $5,7 \%$ kematian semua umur disebabkan oleh kanker ganas. Menurut WHO, 490.000 perempuan didunia setiap tahun didiagnose terkena kanker serviks dan $80 \%$ berada di Negara Berkembang termasuk Indonesia. Setiap 1 menit muncul 1 kasus baru dan setiap 2 menit meninggal 1 orang perempuan karena kanker serviks.

Di Indonesia diperkirakan setiap hari muncul 40-45 kasus baru, 20-25 orang meninggal, berarti setiap 1 jam diperkirakan 1 orang perempuan meninggal dunia karena kanker serviks. Artinya Indonesia akan kehilangan $600-750$ orang perempuan yang masih produktif setiap bulannya. Hal ini mungkin ada kaitannya dengan, sekitar sepertiga dari kasus-kasus kanker termasuk kanker serviks datang ketempat pelayanan kesehatan pada stadium yang sudah lanjut dimana kanker tersebut sudah menyebar ke organ-organ lain di 
seluruh tubuh sehingga biaya pengobatan semakin mahal dan angka kematian semakin tinggi. Disisi lain kesadaran dan pengetahuan masyarakat tentang kanker termasuk faktor-faktor risiko dan upaya pencegahannya masih kurang. Padahal 90-95\% faktor risiko terkena kanker berhubungan dengan perilaku dan lingkungan. Karena itu perlu ada suatu gerakan bersama, menyeluruh dan berkesinambungan untuk meningkatkan kepedulian masyarakat terhadap kanker terutama kanker serviks.

Insiden kanker serviks sebenarnya dapat ditekan dengan melakukan upaya pencegahan primer seperti meningkatkan atau intensifikasi kegiatan penyuluhan kepada masyarakat untuk menjalankan pola hidup sehat, menghindari faktor risiko terkena kanker, melakukan immunisasi dengan vaksin HPV dan diikuti dengan deteksi dini kanker serviks tersebut melalui pemeriksaan pap smear atau IVA (inspeksi visual dengan menggunakan asam acetat). Saat ini cakupan "screening" deteksi dini kanker serviks di Indonesia melalui pap smear dan IVA masih sangat rendah (sekitar 5\%), padahal cakupan "screening" yang efektif dalam menurunkan angka kesakitan dan angka kematian karena kanker serviks adalah $85 \%$.

\section{Metode}

Sasaran dalam kegiatan
penyuluhan ini adalah seluruh
perempuan yang telah menikah di
Desa Pangkalan Lada. Metode yang
dilakukan dalam kegiatan ini adalah
penyuluhan dan pemeriksaan IVA
gratis.

\section{Hasil}

Kegiatan pemeriksaan IVA Test pada wanita usia subur di desa Pangkalan Lada berjalan dengan baik. Antusias dari para peserta cukup baik. Jumlah peserta yang mengikuti pemeriksaan IVA sebanyak 45 orang.

\section{Pembahasan}

Berdasarkan hasil pemeriksaan IVA yang dilakukan pada wanita usia subur di desa Pangkalan Lada, dari 40 peserta yang dilakukan pemeriksaan 10 diantaranya mengalami erosi dan 5 orang diberikan tutul albothyl dan selanjutnya disarankan untuk melakukan pap smear.

\section{Kesimpulan dan Saran Kesimpulan}

Meningkatnya pengetahuan wanita usia subur tentang kanker leher rahim dan pemeriksaan IVA Test. Mendeteksi kanker leher rahim dengan pemeriksaan IVA Test sangat diperlukan untuk menurunkan Angka Kematian akibat kanker leher rahim.

Hasil dan pembahasan dari kegiatan pengabdian ini antara lain :

Pendidikan Kesehatan pada

Wanita Usia Subur tentang Pemeriksaan IVA Test. Tujuan kegiatan ini adalah dapat meningkatkan pengetahuan dan ketrampilan Wanita Usia Subur tentang pemeriksaan IVA Test antara lain Pengertian, Tujuan, Manfaat, Cara Pemeriksaan. Target Luaran yang dicapai: wanita usia subur yang mengikuti kegiatan ini berjumlah 45 orang, peserta dapat mempresentasikan kembali materi yang telah dijelaskan, peserta dapat menjawab pertanyaan yang diberikan oleh tim pengabdian.

Pemeriksaan IVA Test tujuan kegiatan ini adalah untuk mendeteksi dini kanker leher rahim pada wanita usia subur. Sebelum 
dilakukan pemeriksaan IVA Test wanita usia subur di skrinning terlebih dahulu agar dapat mengikuti pemeriksaan. Setelah dilakukan skrinning dari jumlah 45 orang yang dilakukan skrinning terdapat 40 orang yang masuk dalam klasifikasi pemeriksaan. Dan 5 orang lainnya tidak masuk dalam klasifikasi pemeriksaan dikarenakan sedang haid. Setelah dilakukan skrinning maka 40 orang yang masuk dalam klasifikasi pemeriksaan IVA Test selanjutnya dilakukan anamnesa, bertujuan untuk mengetahui informasi yang digali langsung dari peserta. Peserta yang dilakukan anamnesa berjumlah 40 orang. Berdasarkan kegiatan yang telah dilakukan jumlah responden yang melakukan pemeriksaan IVA Test berjumlah 40 orang. Tidak ada responden yang positif terhadap hasil pemeriksaan IVA Test. Tetapi erosi terjadi positif pada 10 orang wanita usia subur kemudian dilakukan tutul abotyl sebanyak 5 orang dan selanjutnya disarankan untuk pemeriksaan pap smear.

\section{Saran}

Agar kegiatan pemeriksaan seperti ini dapat dilakukan secara rutin sehingga derajat kesehatan warga khususnya pada wanitawanita di desa ini dapat meningkat dan terpantau.

\section{Daftar Pustaka}

Adnyana, Nengah. 2012. Skrining. Surakarta: Akademi Analisis Kesehatan Nasional Surakarta [internet]http://aaknasional.wor dpress.com/2012/03/29/skrinin g/Febri.2010. Kesehatan Reproduksi. (http://bidanshop.blogspot.com. Diakses 20 januari 2011).
Dinas Kesehatan Kota Semarang. 2011. Profil Kesehatan Kota Semarang [internet]http://www.dinkeskotas emarang.go.id/?p=halaman mod\&jenis=profil.

Manuaba, Ida Ayu Chandranita. Ida Bagus Gde Fajar Manuaba. Ida Bagus Gede Manuaba. 2009. Memahami Kesehtan Reproduksi Wanita. Jakarta : EGC.

Novel S.Sinta dkk. 2010. Kanker Serviks dan Infeksi Human Pappilomavirus (HPV). Jakarta : Javamedia Network.

Samadi Priyanto.H. 2010. Yes, I Know Everything Abaut KANKER SERVIK. Yogyakarta : Tiga Kelana.

Sukaca E. Bertiani. 2009. Cara Cerdas Menghadapi KANKER SERVIK (Leher Rahim). Yogyakarta: Genius Printika.

Wijaya Delia. 2010. Pembunuh Ganas Itu Bernama Kanker Servik. Yogyakarta: Sinar Kejora.

Wijayanti, Daru. 2009 . Fakta penting Seputar Kesehatan Reproduksi Wanita. Yogyakarta: Book Marks 